DOI:10.24193/tras.52E.5

Published First Online: 2017/10/31

\section{THE LINKAGE BETWEEN WORK UNIT PERFORMANCE PERCEPTIONS \\ OF U.S. FEDERAL EMPLOYEES AND THEIR JOB SATISFACTION: AN EXPECTANCY THEORY}

\section{Soyoung PARK \\ Sungchan KIM}

Abstract

Public organizations are interested in how to improve their performance. Performance in a work unit can also influence employee job satisfaction due to positive expectations based on higher performance. Thus, our study attempts to investigate if organizational performance has an impact on employee motivation under the premise that employees who perform better in a work unit expect greater professional recognition and rewards. By using data from the 2013 Federal Employee Viewpoint Survey (FEVS), we find that employees who perceive higher levels of performance in a work unit have a higher level of job satisfaction. This paper further shows that performance perception based on rewards is also positively related to job satisfaction.

However, underrepresented groups (female and non-white), older employees and mid-level (work experience from 6 to 14 years) employees are less satisfied with higher work unit performance. Finally, employees in the distributive agency category are more satisfied with work unit performance while those in the regulatory agency category are less satisfied with work unit performance. In conclusion, organizations should recognize particular characteristics of employees to develop the policies related to performance management, and effectively utilize these policies in order to attract and retain proficient workers.

Keywords: organizational performance, job satisfaction, expectancy theory.

\section{Soyoung PARK}

$\mathrm{PhD}$, Fiscal Information Research Center, Korea Public Finance Information Service, Seoul, South Korea

Tel.: 0082-26-908.8579

E-mail: soyoungp2@gmail.com

\section{Sungchan KIM (Corresponding author)}

$\mathrm{PhD}$, Local Finance Research Office, Korea Research Institute for Local Administration, Wonju, South Korea Tel.: 0082-33-769.9876
E-mail: thesungchan@gmail.com 


\section{Introduction}

New public management (NPM) reforms have emphasized performance-focused organizational management and the government has become more interested in this management tool to improve its performance. Performance management is being used throughout all governmental entities in the public sector, and as a result, consideration is given to how a newly established policy relates to job functions and performance. Although previous examinations of organizational performance as an overall managerial tool have been undertaken, little empirical research has been conducted to determine the effects of perceived work unit performance on employee motivation in public organizations. Rather, most of these studies have examined the motivation and job satisfaction of employees and their effects on performance. However, performance in the work unit itself can play a role as a motivator for employees, which indicates the relationship might be spurious. Lawler (1971) argues that performance in an individual's work significantly leads to job motivation; more positive perceptions of performance in work unit lead to higher levels of job satisfaction among employees in the organization as a result of expectations related to organizational performance.

Thus, this study attempts to bridge the gap between organizational performance in a work unit and individual behaviors with job satisfaction. More specifically, this study investigates how the perception of organizational performance has an impact on employee job satisfaction under the premise that employees with better performance in a work unit expect greater professional recognition and positive values of rewards. On the other hand, changes to a performance-oriented managerial tool may result in employee uncertainty regarding roles and goals, and this can make it difficult to have conscious expectations of what will happen if employees do certain things. Additionally, emphasis on organizational performance in a work unit (collective action rather than individual action) inserts motives or other forms of job satisfaction at the individual level. As a result, this influences the work motivation of employees toward their jobs. To examine the relationship, this study will use Vroom's expectancy theory, because the theory can explain worker motivation in factors related to worker expectancy under an uncertain job environment, and also as it relates to job expectations (Vroom, 1964). Using data from a survey of U.S. federal employees conducted in 2013, this study attempts to determine if there is a relationship between the perception of organizational performance in a work unit and individual motivations in the public organization; our study uses the perceptual measure of the organization's performance by federal employees.

Job satisfaction of employees in the organization is meaningful to examine because job satisfaction results in positive impacts to the organization as well as the individual. According to Judge and Klinger (2007), increased satisfaction is related to an individual's well-being, and dissatisfaction leads to discontent in personal life. Finally, it results in turnover of employees. The higher the level of job satisfaction, the more workers are likely to have a positive attitude toward their job (Saari and Judge, 2004). In addition, job satisfaction is positively related to organizational citizenship 
behaviors (Organ and Ryan, 1995). This organizational citizenship behavior in the workplace aids in the survival of an organization (Organ, 1988). Furthermore, higher levels of job satisfaction can decrease counterproductive work behaviors in employees (Dalal, 2005), prevent employees from leaving their position (Gleasonwynn and Mindel, 1999), and reduce absenteeism (Hardy, Woods and Wall, 2003).

\section{Literature review}

According to Smith, Kendall and Hulin (1969, p. 6), job satisfaction is defined as 'feelings or affective responses to facets of the (workplace) situation'. Job satisfaction has an important impact on job-related behaviors of employees, such as increased productivity from mental well-being, reduced absenteeism, and retention of employees in the workplace (Meyer, Becker and Vandenberghe, 2004). In addition, higher performance from job satisfaction can lead to improvements in the financial standing of the organization (Aronson et al., 2005). Thus, boosting the job satisfaction of employees is important in the public sector. More recently, researchers have argued that job satisfaction is considered to possess both a 'cognitive (thoughts) and affective (feelings) character' (Cook, 2008, p. 1). For example, Brief and Weiss (2002) proposed that reports of emotion at work by employees can be referenced to evaluate job satisfaction. This cognitive job satisfaction is explained by an expectancy-value theoretical model. In agreement with Vroom's theory, the goal-setting theory (Locke and Latham, 2004) also states that performance precedes job satisfaction.

The expectancy-value theory assumes that individuals with a higher expectancy in terms of outcome will behave differently when compared to those with a low expectancy (Jorgenson and Dunnette, 1973). That is, people with a higher expectancy perceive that a high level of performance in a work unit can yield rewards. This results in employees' feelings of greater satisfaction toward their jobs. Based on this, our study will use the expectancy theory to explain the influence of performance perception in a work unit on the job satisfaction of employees in public organizations.

\subsection{Expectancy theory}

The expectancy theory model, as developed by Vroom (1964), defines motivation as a process of governing choices among alternative forms of voluntary activities, and this process is controlled by the individual. A number of studies have shown that expectancy formulations are potentially useful for predicting work motivation in organizational settings (Hellriegel and Slocum, 2011; Lunenburg, 2011; Mitchell and Biglan, 1971). According to the Vroom's model, employees' beliefs about valence, expectancy and instrumentality interact to build motivation (Vroom, 1964). The three factors must be examined in detail because such an examination is helpful in operationalizing motivational factors.

Expectancy refers to the strength of a person's belief about how particular actions affect performance (Vroom, 1964). Employees have different expectations and different levels of confidence about what they are capable of doing. In addition, valence 
refers to emotional orientations regarding how highly people value outcomes. An outcome is positively valent if an employee would prefer having it to not having it (Vroom, 1964). According to the model, valence is comprised of positive and negative valence. Finally, instrumentality refers to the perception of employees regarding whether they actually achieve what they desire when they perform well. Vroom defines it as a probability belief linking a first outcome (for example, a high level of performance) to a second outcome (a reward) (Starke and Behling, 1975). In the Vroom model, motivation can be explained by considering three factors simultaneously. However, because instrumentality is considered a bridge to connect the first outcome and the second outcome, motivation is expressed as a multiplicative function of the job's attractiveness (valence) and the job seeker's estimate of its likely attainability (expectancy) (Mitchell and Beach, 1976).

\subsection{Organizational performance in expectancy theory}

Our study first tries to find two elements (expectancy and valence) in performance perception to form a bridge between organizational performance and employee motivation. Expectancy in organizational performance can refer to an employee's belief about the total effect or outputs of effort with professional identity. Previous studies also examine professional identity under the expectancy theory (Hong, 2010; Sare and Edward Bales, 2014). An appropriate match between job requirements and abilities or experience is important to the expectancy factor (Wagner and Hollenbeck, 2005). Requirements for public service jobs and employees' abilities to meet the requirements are shown by the performance in a work unit. Here, effort is an input to work for the performance improvement, and performance is a product of outputs from the employees' efforts. Employees expect higher outputs with their efforts. Additionally, the professional identity of public servants is related to work unit performance as higher organizational performance can compel employees to seek a stronger professional identity.

Professionalism has been defined in various ways, according to Schott (1976), but it is more likely to emphasize 'specialized education, autonomy, clear boundaries within which professionals have exclusive prerogative to operate, and differentiation of professional fields from non-professionalized work' (DeHart-Davis and Kingsley, 2005, p. 229). Professional identity is considered an individual's psychological alignment as a professional in a workplace and it also indicates personal work values, skills and knowledge, growth as a person, success and improvement at work, and imagination (Gazzola and Smith, 2007). Thus, higher organizational performance in a work unit can enable employees to believe in their abilities to successfully accomplish a particular task by boosting professional identity.

In terms of performance expectancy for unique tasks, work unit performance influences employees differently, depending on the degree of an individual's professionalization and his or her position. Bureaucratic tasks in the public sector generally result in work alienation, with highly formalized structures (Zeffane, 1993) restricting involvement in core tasks by employees from other sectors. Moreover, it appears dif- 
ficult for public managers to move from one department to another without any professional skills required for specific tasks. In particular, for example, junior managers may suffer from a tendency to lack particular expertise when they enter senior-level management positions (greater required specialization) (McGovern, Hope-Hailey and Stiles, 1998). Likewise, workers with higher professionalization cannot expect to develop their skills in other work environments where no specific expertise is required, because they may feel isolated by their special skills. In addition, professionals might favor an improved professional reputation (Rainey, 1997). Therefore, higher performance in such work units can increase the professionalism of employees in an organization (this is also dependent on the position).

Valence refers to the emotional orientation that people have with respect to outcomes (rewards). Employees' behaviors are the result of valued rewards (Staw, 1977). Valence is comprised of positive valence (promotion, recognition of achievement) and negative valence (punishment, stress, layoff and pressure regarding job procedures). From the perspective of organizational performance, positive valence is achieved by incurring organizational rewards (e.g., higher incentives and faster promotion) for competently finishing duties (Savas, 2000). Pay awards play a role in completing tasks, and employees are provided with a 'shared destiny' using group incentives derived from higher organizational performance.

However, there are some expected valences in organizational performance perception. Most of the critical issues in organizational performance are related to negative valence (Griffin and Moorhead, 2011). Employees may experience disparities in salary or benefits resulting from differences in organizational performance. Potential disparities in wages and benefits between employees are one major concern among public employees in performance-oriented organizational practice (Ozoemena, 2013). Another negative valence is job stress in a performance-oriented organization. An organization that focuses on performance derived from increased workload might negatively affect an employee's work life (Nadeem and Abbas, 2009). Research does exist regarding the effects of individual job characteristics on job satisfaction as well as well-being (e.g. mental health) (Nelson, Cooper and Jackson, 1995).

\section{Hypotheses}

This research examines organizational performance as the antecedents of job satisfaction. Performance causing satisfaction has typically been based on the expectancy-value framework (Locke and Latham, 2004). Locke (1970) demonstrated that satisfaction can be realized as an outcome of performance under the goal-setting theory. Lawler and Porter (1967) argued that high levels of performance would result in rewards and would increase employee's job satisfaction. Based on Vroom's theory and previous literature, we will empirically test several hypotheses in this analysis. The first hypothesis to draw from the literature is that a higher level of performance will lead to a higher level of job satisfaction in a public organization. When employees think that the level of performance in a work unit is high, they recognize the expecta- 
tion that they may receive more rewards (incentives) from the organization and have a higher level of professional identity. Thus, a higher level of performance has a positive relationship with job satisfaction, leading to the following hypotheses:

- Hypothesis 1-1: 'An increase in perceived organizational performance results in higher job satisfaction', and

- Hypothesis 1-2: 'Employees who think that better performance is rewarded more, will have a higher level of job satisfaction than those who do think less'.

The second set of hypotheses pertains to the relationship between the perception of performance in a work unit and job satisfaction based on employees' supervisory position and payment category. Regarding professional identity, as an expectancy factor, supervisors are categorized into a more professionalized group so that they are more sensitive to organizational performance. About this, Porter's series of work $(1962,1963 a, 1963 b, 1963 c)$ demonstrate a manager's level of need fulfillment. Porter (1962) argues that a higher position within management has a strong emphasis on self-actualization related to job satisfaction. In addition, senior levels of employees are more responsible for and concerned about organizational performance than lower-level employees. Thus, in our analysis, we establish a series of hypotheses that supervisors will consider organizational performance more seriously than non-supervisor groups because they are more likely to believe that organizational performance can result in achieving tasks with professionalism, and can bring about higher job satisfaction for them, as follows:

- Hypothesis 2-1:'Supervisors with a higher perceived organizational performance will have a higher level of job satisfaction over non-supervisors', and

- Hypothesis 2-2: 'Employees in a higher payment category, who have a higher perceived organizational performance, will have a higher level of job satisfaction than those in a lower payment category'.

With regard to professional identity, work characteristics can influence tasks related to professionalism; Hall and Tolbert (2005), for example, maintained that some bureaucratic values, such as an emphasis on the technical qualifications of personnel, are commensurate with the degree of professional values. Thus, our study uses job categories in order to reflect task characteristics: distributive, regulatory, redistributive and constituent agencies (Lowi, 1985; Newman, 1994). Distributive agencies are heavily dependent on 'professional and occupational norms, promotion of specialists rather than generalists, limited due process requirements, relatively wide fields of discretion, and limited sensitivity to discriminatory practices' (Kerr, Miller and Reid, 2002, p. 414). Regulatory agencies deal with policies of the government, 'formulating or implementing rules, imposing obligations on individuals, and sanctioning noncompliance' (Lowi, 1985, p. 85). From these categories, the following hypotheses are formulated:

- Hypothesis 3-1: 'Employees in the distributive agency category with a higher perceived organizational performance will have a higher level of job satisfaction than those in constituent categories'; 
- Hypothesis 3-2: 'Employees in the regulatory agency category with a higher perceived organizational performance will have a lower level of job satisfaction than those in constituent categories', and

- Hypothesis 3-3: 'Employees in the redistributive agency category with a higher perceived organizational performance will have a lower level of job satisfaction than those in constituent categories'.

\section{Data and methodology}

\subsection{Data sources and sample}

This study uses a data set from the 2013 Federal Employee Viewpoint Survey (FEVS) published by the U.S. Office of Personnel Management (U.S. OPM, undated). The FEVS was administered to a representative sample of approximately 376,000 employees from 57 sub-agencies under executive branch agencies that participated in the survey. We employ an ordinary least-squares (OLS) regression based on the assumption that the results between OLS and ordered probit analysis will not show any differences in a large sample (Dittrich et al., 2007; Pitts, 2009). Furthermore, coefficients drawn from the OLS analysis are more intuitive and clearer to understand than those of an ordered probit model. Thus, in order to test the hypotheses identified earlier, three results of the OLS regression models are shown in the analysis.

\subsection{Dependent variable}

Our research focuses on overall job satisfaction rather than payment or promotion satisfaction, as Wanous, Sullivan and Malinak (1989, p. 261) assert that 'facet satisfaction correlations will always be lower than overall satisfaction correlations, so it lowers effect size'. Based upon the groundwork of the previous research on the measurement of perceived job satisfaction (Pitts, 2009), we use it as a dependent variable and tap into whether employees perceive that they are satisfied with their job by seeking answers to the following question: 'Considering everything, how satisfied are you with your job?' Respondents were asked to rate the questions on a Likert-type scale from 1 , representing 'very dissatisfied' to 5, representing 'very satisfied.'

\subsection{Independent variables}

The models include two independent variables: perception of work unit performance and rewards based on the perception of performance. First, the perception of work unit performance is defined as the extent to which employees perceive performance in the organization, and it is reflected by responses to the two survey questions as shown in Table 1. Respondents answered each question on a Likert-type scale with values ranging from 1 (strong disagreement) to 5 (strong agreement). The initial eigenvalue is 1.529 , and the Cronbach's alpha is 0.674 .

The other variable is the perception of rewards based on work performance. The variable shows how well rewards are reflected based on the perception of work per- 
formance. Respondents rated the questions according to two Likert-type questions in Table 1. The initial eigenvalue is 1.592, and the Cronbach's alpha is 0.743 .

\subsection{Control variables}

In this analysis, a resource variable for job satisfaction and seven control variables for demographic characteristics of employees were used. According to Pitts (2009), the resource control variable represents 'the influence of resource munificence on outcomes' (Fernandez, 2005; O’Toole and Meier, 1999; Pitts, 2005; Pitts, 2009, p. 13). Furthermore, Pitts (2009) demonstrates that the resource variable has a positive influence on job satisfaction. Six survey items are included as factor score values of the resource variable for job satisfaction. Even though they are indirectly related to one another, they reflect an underlying reliability in terms of factor analysis. The initial eigenvalue is 2.788 , and the Cronbach's alpha for these items is 0.766 . Survey questions and factor analysis results are shown in Table 1.

Table 1: Factor analysis results

\section{Variables}

Factor Loading

(1) The skill level in my work unit has improved in the past year.

0.727

(2) How would you rate the overall quality of work done by your work unit?

0.727

Job Performance Initial Eigenvalue

1.529

Cronbach's Alpha

0.674

(1) Awards in my work unit depend on how well employees perform their jobs.

0.769

(1) Pay raises depend on how well employees perform their jobs.

0.769

Job Performance Initial Eigenvalue

1.592

Cronbach's Alpha

0.743

(1) My work unit is able to recruit people with the right skills.

0.627

(2) I have sufficient resources (for example, people, materials, budget) to get my job done.

0.746

(3) My workload is reasonable.

0.660

(4) Physical conditions (for example, noise level, temperature, lighting, cleanliness in the workplace) allow employees to perform their jobs well.

0.460

(5) How satisfied are you with the training you receive for your present job?

0.623

(6) Considering everything, how satisfied are you with your pay?

0.452

Resource Initial Eigenvalue

2.788

Cronbach's Alpha

0.766

Source: Authors' computations based on U.S. OPM (undated) data

Second, this study includes demographic variables such as supervisory status, gender, nonwhite race, age, work experience, and payment category as dummy variables. According to much of the previous literature, the demographic backgrounds 
of respondents are proven to affect job satisfaction in the organization as well. Thus, in order to reflect the impact of the demographic variables on the result, this study lists a dummy variable that is coded 1 if the respondent is a supervisor or manager, a female employee, or a nonwhite employee, respectively. In terms of age, payment category, and work experience, we contain respondents' demographic characteristics by using a series of dummy variables.

Third, our study uses agency variables in order to determine the relationship between agency category and job satisfaction, as well as between agency category with work unit performance and job satisfaction. According to Lowi (1985) and Newman (1994), agencies can be divided based upon whether the agencies' missions are generally distributive, regulatory or redistributive (Miller, Kerr and Reid, 1999). Table 2 describes the general characteristics and the number of each agency category in federal organizations.

Table 2: Description of distributive, regulatory and redistributive agencies

\begin{tabular}{|c|c|c|}
\hline Agency & $\mathbf{N}$ & Example \\
\hline Distributive Agencies & 14 & $\begin{array}{l}\text { Department of Air Force, Army or Navy } \\
\text { National Science Foundation } \\
\text { Department of Transportation }\end{array}$ \\
\hline Regulatory Agencies & 19 & $\begin{array}{l}\text { Department of Commerce } \\
\text { Department of Labor } \\
\text { Environmental Protection Agency }\end{array}$ \\
\hline Redistributive Agencies & 9 & $\begin{array}{l}\text { Social Security Administration } \\
\text { Department of Health and Human Service } \\
\text { Department of Housing and Urban Development }\end{array}$ \\
\hline Constituent Agencies & 15 & Residual group of agencies \\
\hline Total & 57 & \\
\hline
\end{tabular}

Source: Authors' computations based on U.S. OPM (undated) data

\subsection{Model specifications}

In this analysis, the model of work unit performance and job satisfaction categorizes the independent variables into three steps and places them in the following order: (1) the basic effect of control variables (Model 1: using only the control variable in the model); (2) the effect of work unit performance and the perception of rewards based on work unit performance (Model 2: using the perception of work unit performance and rewards based on the performance as independent variables without interaction in the model); and (3) the perception of rewards based on work unit performance and perception of work unit performance with interactions with gender, supervisory status, race, age, agency category, payment category, and employees' work experience (Model 3: full model of the perception of rewards based on work unit performance, the perception of work unit performance, and interaction terms with work unit performance). The basic descriptive statistics are listed in Table 3. 
Table 3: Descriptive statistics

\begin{tabular}{|c|c|c|c|c|c|}
\hline Variables & Mean & SD & Min & Max & Unit (Number of observations) \\
\hline Supervisor & 0.18 & 0.39 & 0 & 1 & Supervisor or manger $=1(68,435)$ \\
\hline Female & 0.44 & 0.50 & 0 & 1 & Female $=1(165,428)$ \\
\hline Nonwhite & 0.30 & 0.46 & 0 & 1 & Nonwhite $=1(112,942)$ \\
\hline Ages 40-49 & 0.25 & 0.43 & 0 & 1 & Ages 40 to $49=1(94,643)$ \\
\hline Ages 50-59 & 0.33 & 0.47 & 0 & 1 & Ages 50 to $59=1(122,347)$ \\
\hline Age 60 or older & 0.12 & 0.33 & 0 & 1 & Age 60 or older $=1(46,372)$ \\
\hline GS 7-12 & 0.39 & 0.49 & 0 & 1 & $\begin{array}{l}\text { Pay category/grade from GS } \\
\text { (General Services Administration) } 7 \text { to } 12=1(145,690)\end{array}$ \\
\hline GS 13-15 & 0.36 & 0.48 & 0 & 1 & $\begin{array}{l}\text { Pay category/grade from GS } \\
\text { (General Services Administration) } 13 \text { to } 15=1(136,334)\end{array}$ \\
\hline $6-14$ years & 0.29 & 0.45 & 0 & 1 & Work experience for 6 to 14 years $=1(109,520)$ \\
\hline Over 15 years & 0.42 & 0.49 & 0 & 1 & Work experience for more than 15 years $=1(157,187)$ \\
\hline Distributive & 0.44 & 0.50 & 0 & 1 & Distributive agency $=1(165,996)$ \\
\hline Regulatory & 0.25 & 0.43 & 0 & 1 & Regulatory agency = $1(94,896)$ \\
\hline Redistributive & 0.14 & 0.35 & 0 & 1 & Redistributive agency = $1(53,454)$ \\
\hline Job Satisfaction & 3.55 & 1.04 & 1 & 5 & Average of two Likert-type scale values \\
\hline Rewards & 0 & 0.86 & -1.37 & 1.84 & Factor score \\
\hline Job Performance & 0 & 0.83 & -2.98 & 1.12 & Factor score \\
\hline Resource & 0 & 0.89 & -2.36 & 1.89 & Factor score \\
\hline
\end{tabular}

Note: $n=376,577$

Source: Authors' computations based on U.S. OPM (undated) data

\section{Results}

The results from each model are shown in Table 4. The first model (Model 1), in which only control variables are included, demonstrates that the resource, supervisor, female, older and higher level payment grade groups have a positive impact on job satisfaction, and all of these are statistically significant. That is, supervisors are more satisfied with their jobs than non-supervisors. Female employees are more satisfied with their jobs than male employees. Employees with a higher level of resources are more satisfied with their jobs compared to employees with fewer resources. Older employees are more satisfied with their jobs than young employees. And employees at a higher payment grade are more satisfied with their jobs compared to employees at a lower payment grade. However, work experience has a negative impact on job satisfaction and demonstrates that experienced federal employees feel less satisfied with their jobs than less experienced employees. In addition, nonwhite employees perceive negative job satisfaction compared with white employees. Finally, in terms of agency category, employees in distributive, redistributive, and regulatory agencies are more satisfied with their jobs than those in constituent agencies. 
Table 4: Regression model results for job satisfaction

\begin{tabular}{|c|c|c|c|c|c|c|}
\hline \multirow{2}{*}{ Variables } & \multicolumn{2}{|c|}{ Model 1} & \multicolumn{2}{|c|}{ Model 2} & \multicolumn{2}{|c|}{ Model 3} \\
\hline & Coefficient & Std. Err. & Coefficient & Std. Err. & Coefficient & Std. Err. \\
\hline Resource & $0.783^{\star * *}$ & 0.001 & $0.478^{\star * *}$ & 0.002 & $0.479^{* * *}$ & 0.002 \\
\hline Supervisor & $0.227^{\star \star *}$ & 0.003 & $0.098^{\star * *}$ & 0.004 & $0.096^{\star * *}$ & 0.004 \\
\hline Female & $0.030^{* * *}$ & 0.003 & $0.012^{* * *}$ & 0.003 & $0.011^{* * *}$ & 0.003 \\
\hline Nonwhite & $-0.043^{* * *}$ & 0.003 & $-0.022^{* * *}$ & 0.003 & $-0.022^{* * *}$ & 0.003 \\
\hline Ages 40-49 & $0.045^{\star * *}$ & 0.004 & $0.052^{* * *}$ & 0.004 & $0.052^{* * *}$ & 0.004 \\
\hline Ages 50-59 & $0.085^{\star * *}$ & 0.004 & $0.085^{* * *}$ & 0.004 & $0.085^{* * *}$ & 0.004 \\
\hline Age 60 or older & $0.116^{\star * *}$ & 0.005 & $0.117^{\star \star *}$ & 0.005 & $0.119^{* * *}$ & 0.005 \\
\hline GS 7-12 & $0.007^{*}$ & 0.004 & $-0.026^{* * *}$ & 0.004 & $-0.026^{\star * *}$ & 0.004 \\
\hline GS 13-15 & $0.039^{* * *}$ & 0.004 & $-0.023^{* * *}$ & 0.004 & $-0.026^{\star * *}$ & 0.004 \\
\hline $6-14$ years & $-0.065^{\star \star \star}$ & 0.004 & 0.000 & 0.004 & 0.000 & 0.004 \\
\hline Over 15 years & $-0.081^{* * *}$ & 0.004 & -0.004 & 0.004 & -0.005 & 0.004 \\
\hline Distributive & $0.028^{\star * *}$ & 0.004 & $0.043^{\star * *}$ & 0.004 & $0.044^{\star * *}$ & 0.004 \\
\hline Regulatory & $0.070^{\star * *}$ & 0.004 & $0.035^{\star \star *}$ & 0.005 & $0.037^{\star * *}$ & 0.005 \\
\hline Redistributive & $0.051^{\star * *}$ & 0.005 & $0.024^{\star * *}$ & 0.005 & $0.024^{\star * *}$ & 0.005 \\
\hline Rewards & & & $0.195^{\star \star *}$ & 0.002 & $0.195^{\star \star *}$ & 0.002 \\
\hline Performance (Per) & & & $0.327^{\star \star *}$ & 0.002 & $0.342^{* * *}$ & 0.006 \\
\hline Per×Supervisor & & & & & -0.007 & 0.005 \\
\hline Per×Female & & & & & $-0.018^{* * *}$ & 0.004 \\
\hline Per×Nonwhite & & & & & $-0.057^{\star * *}$ & 0.004 \\
\hline Per×Ages 40-49 & & & & & -0.003 & 0.005 \\
\hline Per×Ages 50-59 & & & & & $-0.019^{* * *}$ & 0.005 \\
\hline Per×Age 60 or older & & & & & $-0.036^{* * *}$ & 0.007 \\
\hline Per×GS 7-12 & & & & & 0.007 & 0.005 \\
\hline Per×GS 13-15 & & & & & $0.066^{* * *}$ & 0.005 \\
\hline Per×6-14 years & & & & & $-0.010^{* *}$ & 0.005 \\
\hline Per×Over 15 years & & & & & -0.004 & 0.005 \\
\hline Per×Distributive & & & & & $0.011^{* *}$ & 0.005 \\
\hline Per×Regulatory & & & & & $-0.014^{* *}$ & 0.006 \\
\hline Per×Redistributive & & & & & -0.003 & 0.006 \\
\hline $\mathrm{R}^{2}$ & 0.681 & & 0.689 & & 0.69 & \\
\hline
\end{tabular}

Note: ${ }^{* * *},{ }^{* *}$, and ${ }^{*}$ indicate significance at the level of $1 \%, 5 \%$, and $10 \%$, respectively.

Source: Authors' computations based on U.S. OPM (undated) data

The second model (Model 2), in which the perception of rewards based on the performance and performance perception itself are included as a factor score, shows results similar to the first model. In addition, the rewards variable has a positive impact on job satisfaction, and the performance perception variable is positively related to job satisfaction as well. A higher rate of work unit performance leads to greater job satisfaction, controlling for other variables. Similar to the first model, the nonwhite group and higher-payment grade (GS 7-12 and GS 13-15) are less satisfied with their jobs, and they are statistically significant at the level of $1 \%$. Other variables, such as 
supervisor, female and older group are positively related to the job satisfaction. Regarding the agency category, employees in distributive, redistributive and regulatory agencies are more satisfied with their jobs than those in the constituent agency when the performance variable is included in the model.

Finally, the full model, which includes the perception of rewards based on the performance and performance perception along with its interactions between the perception of work unit performance and other demographic variables (Model 3), reveals a detailed relationship between the perception of work unit performance and job satisfaction. First, the general perception of work unit performance is positively related to job satisfaction; perception of rewards based on performance also has a positive impact on job satisfaction. Regarding interaction terms, female employees who perceive a higher level of work unit performance are less satisfied than males with a higher perceived level of work unit performance. Nonwhite employees who perceive a higher level of work unit performance are also less satisfied when compared with whites. Older people (over 50 years of age) with a higher level of perception in terms of work unit performance are less satisfied with their jobs when compared with younger employees. Additionally, employees in the higher level payment category (GS 13-15) believe that a higher level of perception in terms of work unit performance will result in a higher level of job satisfaction more than those in the lowest level payment category.

Federal employees with 6 to 14 years of work experience believe that a higher level of perception in terms of work unit performance will lead to a lower level of job satisfaction over those from the lowest and highest levels of job experience groups. In addition, employees in the distributive agency category perceive that a higher level of work unit performance is positively related to job satisfaction more than those in other agency categories. However, federal employees in the regulatory agency category believe that a higher level of perception in terms of work unit performance will have a negative impact on job satisfaction more strongly than those in other agency categories.

\section{Conclusion and discussion}

This study has begun to address the perception of work unit performance on job satisfaction, and how it has an impact on job satisfaction based on federal employees' demographic factors. Our findings related to expectancy and valence in work unit performance may contribute to the advancement of Vroom's expectancy theory. Our study contributes to the expansion of the theory to the work unit level from the individual level phenomena. The expectancy theory is used as a framework for an organizational model because the theory can explain job satisfaction from cognitive oriented assumptions by emphasizing workers' expectations and perceptions regarding organizational performance. In addition, there are several meaningful findings that warrant mention. First of all, this study confirms that higher work unit performance has a positive impact on job satisfaction. The finding explains that the expectancy (professional identity) and valences (job stress, perception of rewards) of higher work 
unit performance for federal employees determine job satisfaction based on Vroom's theory. Our finding indicates that employees' positive valence leads to job satisfaction by getting rewards for performing their tasks (assuming rewards are desirable by employees). Thus, pay awards play a role in completing tasks and lead to the mind of a 'shared destiny' from higher organizational performance in a work unit. While Lawler and Porter (1967) also demonstrate that performance precedes job satisfaction through the realization of intrinsic and extrinsic rewards, our model using Vroom's theory also provides consistent findings with Lawler and Porter (1967).

Our finding is also partially compatible with Porter's series of works (1962, 1963a, 1963b, 1963c), which demonstrate that higher level managerial positions perceive greater job satisfaction through an emphasis on self-actualization. Porter used Maslow's hierarchy as the framework to influence managers' level for need fulfillment arguing that managers at higher levels have higher satisfaction in performing tasks that fulfill the desire for self-actualization. That is, his studies assume that different groups of employees want different things from an organization. This is similar to the assumptions in Vroom's theory we employ. Our study posits that self-actualization (professional identity) in the public sector can be realized in all employees regardless of supervisory status, but the level of self-actualization in terms of professional identity can differ depending upon other factors (i.e., work experience).

Although we have obtained meaningful results in this study, there are some limitations. First of all, job satisfaction is not built solely from those variables listed in the study and in order to achieve greater generalization, other variables, such as work environment or interpersonal relationships, must be investigated. Moreover, this study analyzes the relationships between the perception of work unit performance and job satisfaction under control of certain demographic characteristics. In the future, other organizational characteristics and managerial practices must be considered. Furthermore, additional measures and approaches should be employed in order to tap into all aspects of this issue and to combine data sets of both the survey and other sources in order to examine the effect of the perception of work unit performance on job satisfaction in public organizations.

However, this study may contribute to other studies in the future, because there have been few studies dealing with the effect of organizational performance on employees' behavior, especially employees' work motivation at the individual level of the public sector. In addition, there has been no study of the effects of organizational performance on motivation based on Vroom's expectancy theory. In terms of a pioneering assessment, this study may hold additional significance. In particular, this study is applicable to the expectancy theory because Vroom's theory can provide the framework to explain workers' motivations in a work environment of evolving, potentially volatile settings stemming from newly adopted, performance-based managerial practices. Moreover, our study has expanded Vroom's theory by including employees' characteristics, because Vroom's theory can only explain workers' motivations without considering individual differences. 
Finally, this study will contribute to the knowledge related to how decision makers in the arena of organizational performance can formulate specific guidelines to improve employees' motivation. Organizations must recognize the importance of certain components of policies related to performance management and effectively utilize these policies in order to attract and retain proficient workers.

\section{References:}

1. Aronson, K.R., Laurenceau, J., Sieveking, N. and Bellet, W., 'Job Satisfaction as a Function of Job Level', 2005, Administration and Policy in Mental Health and Mental Health Services Research, vol. 32, no. 3, pp. 285-291.

2. Brief, A.P. and Weiss, H.M., 'Organizational Behavior: Affect in the Workplace', 2002, Annual Review of Psychology, vol. 53, pp. 279-307.

3. Cook, A.L., 'Job Satisfaction and Job Performance: Is the Relationship Spurious?', Master thesis, Texas A\&M University, 2008, [Online] available at http://oaktrust.library. tamu.edu/bitstream/handle/1969.1/ETD-TAMU-3052/COOK-THESIS.pdf?sequence=1, accessed on March 5, 2017.

4. Dalal, R.S., 'A Meta-analysis of the Relationship between Organizational Citizenship Behavior and Counterproductive Work Behavior', 2005, Journal of Applied Psychology, vol. 90, no. 6, pp. 1241-1255.

5. DeHart-Davis, L. and Kingsley, G., 'Managerial Perceptions of Privatization: Evidence from a State Department of Transportation', 2005, State \& Local Government Review, vol. 37, no. 3, pp. 228-241.

6. Dittrich, R., Francis, B., Hatzinger, R. and Katzenbeisser, W., 'A Paired Comparison Approach for the Analysis of Sets of Likert-scale Responses', 2007, Statistical Modeling, vol. 7, no. 1, pp. 3-28.

7. Fernandez, S., 'Developing and Testing an Integrative Framework of Public Sector Leadership: Evidence from the Public Education Arena', 2005, Journal of Public Administration Research and Theory, vol. 15, no. 2, pp. 197-217.

8. Gazzola, N. and Smith, J.D., 'Who Do We Think We Are? A Survey of Counselors in Canada', 2007, International Journal for the Advancement of Counselling, vol. 29, no. 2, pp. 97-110.

9. Gleasonwynn, P. and Mindel, C.H.,' 'A Proposed Model for Predicting Job Satisfaction among Nursing Home Social Workers', 1999, Journal of Gerontological Social Work, vol. 32, no. 3, pp. 65-79.

10. Griffin, R.W. and Moorhead, G., Organizational Behavior, Mason, US: Cengage Learning, 2011.

11. Hall, R.H. and Tolbert, P.S., Organizations: Structures, Processes, and Outcomes, Upper Saddle River, NJ: Pearson Prentice Hall, 2005.

12. Hardy, G.E., Woods, D. and Wall, T.D., 'The Impact of Psychological Distress on Absence from Work', 2003, Journal of Applied Psychology, vol. 88, no. 2, pp. 306-314.

13. Hellriegel, D. and Slocum, J.W., Organizational Behavior, $13^{\text {th }}$ edition, Mason, OH: South-Western Cengage Learning, 2011.

14. Hong, J.Y., 'Pre-service and Beginning Teachers' Professional Identity and Its Relation to Dropping out of the Profession', 2010, Teaching \& Teacher Education, vol. 26, no. 8, pp. 1530-1543. 
15. Jorgenson, D.O. and Dunnette, M.D., 'Effects of the Manipulations of a Performance-reward Contingency on Behavior in a Stimulated Work Setting', 1973, Journal of Applied Psychology, vol. 57, no. 3, pp. 271-280.

16. Kerr, B., Miller, W. and Reid, M., 'Sex-Based Occupational Segregation in US State Bureaucracies, 1987-97', 2002, Public Administration Review, vol. 62, no. 4, pp. 412-423.

17. Lawler, E.E. and Porter, L.W., 'The Effect of Performance on Job Satisfaction', 1967, Industrial Relations, vol. 7, no. 1, pp. 20-28.

18. Lawler, E.E., Pay and Organization Effectiveness: A Psychological View, New York: McGraw-Hill, 1971.

19. Locke, E.A. and Latham, G.P., 'What Should We Do About Motivation Theory? Six Recommendations for the Twenty-first Century', 2004, Academy of Management Review, vol. 29, no. 3, pp. 388-403.

20. Locke, E.A., 'Job Satisfaction and Job Performance: A Theoretical Analysis', 1970, Organizational Behavior and Human Performance, vol. 5, no. 5, pp. 484-500.

21. Lowi, T.J., 'The State in Politics: The Relation between Policy and Administration', in Noll, R.G. (ed.), Regulatory Policy and the Social Sciences, Berkeley, CA: University of California Press, 1985, pp. 67-105.

22. Lunenburg, F.C., 'Expectancy Theory of Motivation: Motivating by Altering Expectations', 2011, International Journal of Management, Business, and Administration, vol. 15, no. 1, pp. 1-6.

23. McGovern, P., Hope-Hailey, V. and Stiles, P., 'The Managerial Career after Downsizing: Case Studies from the 'Leading Edge', 1998, Work, Employment and Society, vol. 12, no. 3, pp. 457-477.

24. Meyer, J.P., Becker, T.E. and Vandenberghe, C., 'Employee Commitment and Motivation: A Conceptual Analysis and Integrative Model', 2004, Journal of Applied Psychology, vol. 89, no. 6, pp. 991-1007.

25. Miller, W., Kerr, B. and Reid, M., 'A National Study of Gender-based Occupational Segregation in Municipal Bureaucracies: Persistence of Glass Walls?', 1999, Public Administration Review, vol. 59, no. 3, pp. 218-230.

26. Mitchell, T.R. and Beach, L.R., 'A Review of Occupational Preference and Choice Research Using Expectancy Theory and Decision Theory', 1976, Journal of Occupational Psychology, vol. 49, no. 4, pp. 231-248.

27. Mitchell, T.R. and Biglan, A., 'Instrumentality Theories: Current Uses in Psychology', 1971, Psychological Bulletin, vol. 76, no. 6, pp. 432-454.

28. Nadeem, M.S. and Abbas, Q., 'The Impact of Work Life Conflict on Job Satisfactions of Employees in Pakistan', 2009, International Journal of Business and Management, vol. 4, no. 5, pp. 63-83.

29. Nelson, A., Cooper, C.L. and Jackson, P.R., 'Uncertainty amidst Change: The Impact of Privatization on Employee Job Satisfaction and Well-being', 1995, Journal of Occupational and Organizational Psychology, vol. 68, no. 1, pp. 57-71.

30. Newman, M.A., 'Gender and Lowi's Thesis: Implications for Career Advancement', 1994, Public Administration Review, vol. 54, no. 3, pp. 277-284.

31. O'Toole, L.J. and Meier, K.J., 'Modeling the Impact of Public Management: Implications of Structural Context', 1999, Journal of Public Administration Research and Theory, vol. 9, no. 4, pp. 505-526. 
32. Organ, D.W. and Ryan, K., 'A Meta-analytic Review of Attitudinal and Dispositional Predictors of Organizational Citizenship Behavior', 1995, Personnel Psychology, vol. 48, no. 4, pp. 775-802.

33. Organ, D.W., Organizational Citizenship Behavior: The Good Soldier Syndrome, Lexington, MA: Lexington Books, 1988.

34. Ozoemena, P.O., 'Manpower Development and Utilization in Adult Literacy Education in Nigeria', 2013, African Educational Research Journal, vol. 1, no. 2, pp. 102-112.

35. Pitts, D.W., 'Diversity Management, Job Satisfaction, and Performance: Evidence from US Federal Agencies', 2009, Public Administration Review, vol. 69, no. 2, pp. 328-338.

36. Pitts, D.W., 'Diversity, Representation, and Performance: Evidence about Race and Ethnicity in Public Organizations', 2005, Journal of Public Administration Research and Theory, vol. 15, no. 4, pp. 615-631.

37. Porter, L.W., 'Job Attitudes in Management: I. Perceived Deficiencies in Need Fulfillment as a Function of Job Level', 1962, Journal of Applied Psychology, vol. 46, no. 6, pp. 375-384.

38. Porter, L.W., 'Job Attitudes in Management: II. Perceived Importance of Needs as a Function of Job Level', 1963a, Journal of Applied Psychology, vol. 47, no. 2, pp. 141-148.

39. Porter, L.W., 'Job Attitudes in Management: III. Perceived Deficiencies in Need Fulfillment as a Function of Line versus Staff Type of Job', 1963b, Journal of Applied Psychology, vol. 47, no. 4, pp. 267-275.

40. Porter, L.W., 'Job Attitudes in Management: IV. Perceived Deficiencies in Need Fulfillment as a Function of Size of Company', 1963c, Journal of Applied Psychology, vol. 47, no. 6, pp. 386-397.

41. Rainey, H.G., Understanding and Managing Public Organizations, $2^{\text {nd }}$ edition, San Francisco, CA: Jossey-Bass, 1997.

42. Saari, L.M. and Judge, T.A., 'Employee Attitudes and Job Satisfaction', 2004, Human Resource Management, vol. 43, no. 4, pp. 395-407.

43. Sare, L. and Edward Bales, S., 'Professional Identity: A Grounded Theory Study of Veteran Academic Librarians', 2014, Library Review, vol. 63, no. 8/9, pp. 574-589.

44. Savas, E.S., Privatization and Public-private Partnerships, Chatham, NJ: Chatham House, 2000.

45. Schott, R.L., 'Public Administration as a Profession: Problems and Prospects', 1976, Public Administration Review, vol. 36, no. 3, pp. 253-259.

46. Smith, P.C., Kendall, L.M. and Hulin, C.L., The Measurement of Satisfaction in Work and Retirement, Chicago, IL: Rand McNally, 1969.

47. Starke, F.A. and Behling, O., 'A Test of Two Postulates Underlying Expectancy Theory', 1975, The Academy of Management Journal, vol. 18, no. 4, pp. 703-714.

48. Staw, B.M., 'Motivation in Organizations: Toward Synthesis and Redirection', in Staw, B.M. and Salancik, G.R. (eds.), New Directions in Organizational Behavior, Chicago, IL: St. Clair Press, 1977, pp. 55-96.

49. U.S. Office of Personnel Management (U.S. OPM), '2013 Federal Employee Viewpoint Survey', (undated), [Online] available at www.fedview.opm.gov/2013/Reports/, accessed on February 26, 2017.

50. Vroom, V.H., Work and Motivation, New York: Wiley, 1964. 
51. Wagner III, J.A. and Hollenbeck, J.R., Organizational Behavior: Securing Competitive Advantage, Mason, OH: Thomson South-Western, 2005.

52. Wanous, J.P., Sullivan, S.E. and Malinak, J., 'The Role of Judgment Calls in Meta-analysis', 1989, Journal of Applied Psychology, vol. 74, no. 2, pp. 259-264.

53. Zeffane, R., 'Uncertainty, Participation and Alienation: Lessons for Workplace Restructuring', 1993, International Journal of Sociology and Social Policy, vol. 13, no. 5/6, pp. 22-52. 